\title{
Mídia ElETRôniCA DE MASSA E POLÍTICA
}

\author{
Rafael de Paula Aguiar Araújo ${ }^{1}$
}

\begin{abstract}
Resumo
0 presente artigo discute a relação entre mídia e política, considerando os efeitos sobre a formação da opinião pública e suas conseqüências para o mecanismo democrático. Para isso, foi feita uma revisão bibliográfica tratando diferentes posturas de teóricos a fim de se fomentar a discussão sobre a comunicação de massa e o desenvolvimento político.

Palavras-chave: Mídia. Política. Democracia. Comunicação de Massa. Desenvolvimento Político.
\end{abstract}

\begin{abstract}
The present article discusses the relationship between the media and politics, considering its effects on the formation of public opinion and its consequences for the democratic mechanism. To that end, a bibliographic review was done that examines the different positions adopted by theorists, in order to foment a discussion on mass communications and political development.

Keywords: Media. Politics. Democracy. Mass Communications. Political Development.
\end{abstract}

\footnotetext{
${ }^{1}$ Professor da Escola de Sociologia e Política de São Paulo, Mestre e doutorando em Ciências Sociais pela Pontifícia Universidade Católica de São Paulo, Pesquisador do Núcleo de Estudos em Arte, Mídia e Política (NEAMP) do Programa de Estudos Pós-Graduados em Ciências Sociais da PUC-SP.
} 


\section{INTRODUÇÃO}

mídia eletrônica de massa, especialmente a televisão, contribui para $A$ a diversificação do universo simbólico humano, mas também o 1 homogeneíza. Aumenta as possibilidades de lazer do homem, mas prejudica o desenvolvimento de seu aparato cognitivo. Ao mesmo tempo em que a televisão divulga os candidatos e seus programas de governos para o eleitor, ela pode distorcer fatos e inverter prioridades, notadamente, durante as campanhas eleitorais. Diante dos diversos pontos de vista existentes sobre a mídia de massa, queremos levantar alguns argumentos de autores - algumas vezes excludentes - que esclareçam a subjetividade existente entre 0 emissor, a informação e o receptor, para um entendimento mais maduro do papel da mídia na formação da opinião pública.

A comunicação é apenas um dos contextos da vida social. Possivelmente, 0 mais importante. Mas deve ser encarada como parte de um todo. As relações sociais são intermediadas pela comunicação, seja ela de que ordem for. Não cabe aqui a enumeração das ações existentes em uma sociedade complexa, mas sim observar a comunicação de massas como o elemento capilar do complicado organismo social, capaz de mediar as ações dos homens. Ao exercer essa função, por conseqüência, deve ser encarada como uma ação independente, e, por isso, devemos voltar nossa atenção para o movimento das estruturas sociais que estão vinculadas à circulação de informações.

Este artigo procura discutir a relação existente entre mídia e política. Para isso, toma como interesse a mídia eletrônica, mais especificamente a televisão, como fenômeno de massa pertencente ao cotidiano das pessoas. A facilidade com que as informações são veiculadas na contemporaneidade requer um olhar cuidadoso por parte dos pesquisadores, no intuito de se verificar a forma como os processos políticos são modificados pela presença de um meio de comunicação centrado na imagem. Quais os efeitos de uma comunicação assim para o universo simbólico do cidadão e suas conseqüências para o desenvolvimento democrático são alguns dos fatores que justificam o tema em questão.

\section{Comunicação e Poder Simbólico}

Se linguagem é uma forma pela qual os indivíduos estabelecem e reiteram relações uns com os outros, a ação comunicativa ${ }^{2}$ pressupõe uma relação de poder.

${ }^{2} 0$ termo é usado aqui para designar a comunicação como ação independente e coincide com 0 
John Thompson, no seu Mídia e Modernidade, estabelece quatro tipos distintos de poder: o econômico; o político; o coercitivo e o simbólico. A comunicação media todas essas formas de poder, mas está mais intimamente relacionada ao poder simbólico. Essa tipologia não pode ser entendida de maneira isolada, porque as formas de poder estão imbricadas. Ao comparar sua distinção de poderes com a teoria de Max Weber, Thompson assegura que Weber chamaria de poder o que ele atribuiu ao poder coercitivo e simbólico. Weber diria que uma relação de poder ocorre quando um indivíduo leva outro indivíduo a fazer algo que não faria se estivesse sozinho ${ }^{3}$. Thompson nos diz que a coerção e a simbolização são maneiras de promover essa ação.

Vamos centrar nossa atenção no que Thompson definiu como poder simbólico, porque nos aproxima de uma leitura interessante sobre a comunicação de massas.

0 poder simbólico é "a capacidade de intervir no curso dos acontecimentos, de influenciar as ações dos outros e produzir eventos por meio da produção e da transformação de formas simbólicas" (THOMPSON, 2001, p.24). Uma ação simbólica gera reações nos indivíduos, que não são necessariamente reflexos de um desconhecimento das bases sociais do poder. A ação simbólica deve ser vista com a perspectiva de um compartilhamento de significados entre emissor e receptor, que pode ou não acontecer. A ação simbólica pode, portanto, "provocar reações, liderar respostas de determinado teor, sugerir caminhos e decisões, induzir a crer e a descrer, apoiar os negócios do estado ou sublevar as massas em revolta coletiva" (p.24).

Mesmo assegurando seu pensamento estar pautado pela tradição hermenêutica ${ }^{4}$, Thompson levanta as possibilidades de um poder simbólico. Não raro, encontramos pensadores dos meios de comunicação de massa usando a hermenêutica como justificativa para uma recepção da informação ativa e isenta

conceito de Habermas. Para ele, ação comunicativa é a ação voltada para o entendimento mútuo e baseia-se num processo cooperativo de interpretação. Embora nosso raciocínio não esteja baseado na teoria de Habermas, a definição do conceito é pertinente. Cf. Freitag e Rouanet (1993).

3 "Weber define o poderio como a oportunidade de um indivíduo de fazer triunfar no seio de uma relação social sua própria vontade contra resistências" (WEBER,1944 apud FREUND, 2000, p.161).

${ }^{4}$ Mais a frente voltaremos a tratar a tradição hermenêutica, que propõe a recepção da informação como um processo dinâmico. 
de manipulação. Os argumentos de Thompson não entram necessariamente em desacordo com o pensamento de autores como Pierre Bourdieu e Giovanni Sartori. Ao levantar a possibilidade do poder simbólico intervir nos acontecimentos com conseqüências as mais diversas, Thompson confirma a importância da distinção da forma como cada indivíduo vai receber uma informação da maneira como essa informação foi construída. Daí a preocupação em identificar aspectos na comunicação que revelem alguma intenção do comunicador (instituição ou indivíduo), qualquer que seja, porque isso pode significar a confirmação da hipótese de ação política (poder simbólico) e não apenas a emissão passiva de informação.

A comunicação, enquanto atividade social, além da recepção, envolve a produção e a transmissão de formas simbólicas. Para produzir e transmitir uma informação, indivíduos utilizam meios técnicos diversos. Cada qual apresenta características distintas quanto ao grau de fixação da mensagem, que exigem atenção particular porque indicam possibilidades diferentes de exercício de poder. Essas possibilidades também se alteram quanto ao grau de distanciamento espaçotemporal que determinado meio de comunicação permite. Com a utilização de meios técnicos para a mediação, indivíduos podem influenciar o curso dos acontecimentos em uma distância mais ampla que o "aqui", e em um tempo mais amplo que o "agora". "0 uso dos meios técnicos dá aos indivíduos novas maneiras de organizar e controlar o espaço e o tempo, e novas maneiras de usar 0 tempo e o espaço para os próprios fins" (THOMPSON, 2001, p.29).

Para codificar uma mensagem, é necessário um conhecimento diferente do necessário para decodificá-la. Qualquer indivíduo pode decodificar uma mensagem passada pela televisão sem que tenha o conhecimento técnico para produzi-la. Ao fazer isso, o indivíduo está empregando não apenas as habilidades exigidas pelo meio técnico - no caso da televisão, por exemplo, a visão -, mas também outras formas de conhecimento e suposições resultantes de um acúmulo de informações culturais e de experiências adquiridas por meio da sua relação com o ambiente em que se insere. Esses conhecimentos dão forma particular à mensagem. "0 processo de compreensão é sempre uma ação recíproca entre as mensagens codificadas e os intérpretes situados, e estes sempre trazem uma grande quantidade de recursos culturais de apoio a este processo" (THOMPSON, 2001, p.30). A idéia de que os receptores são meros espectadores passivos cuja sensibilidade foi atrofiada pela contínua presença de mensagens padronizadas deve ser descartada e substituída por uma postura mais dinâmica. Esse dinamismo do receptor no processo 
comunicacional significa uma divisão de responsabilidades necessária para que se encare o poder simbólico de forma plural e ambivalente.

Thompson, ao adotar a tradição hermenêutica para entender o processo de recepção de informações através dos meios de comunicação de massa, não está eliminando a hipótese de poder simbólico, pelo contrário, está nos chamando a atenção para o fato de que é possível coexistir uma ação dotada de aspectos ideológicos e objetivos mercadológicos com uma participação ativa dos sujeitos envolvidos de ambas as partes.

A participação dos que recebem a informação envolve uma interpretação que atribui sentido aos produtos da mídia5. 0 indivíduo que recebe o produto, ao desprender atenção para decodificar a mensagem nele embutida, está buscando entender o seu conteúdo simbólico. Essa atenção varia de acordo com o produto. No caso da televisão, pode-se empregar diferentes graus de atenção, coisa que não ocorre com um livro, por exemplo, que exige um mínimo de atenção para o seu entendimento ${ }^{6}$.

A interpretação é um processo ativo e criativo; portanto, requer uma participação dialógica 7 . 0 intérprete contribui para 0 significado da informação com suposições e expectativas que amparam o seu entendimento. Elas podem ter origem em experiências pessoais ou mesmo ser de ordem sócio-histórica, sendo compartilhadas por um grupo mais abrangente. Nesse caso, às experiências comuns, são somadas as experiências pessoais. Isso garante particularidade ao processo interpretativo, pois essas características compartilhadas funcionam como uma estrutura apriorística que permite assimilar e interpretar o que é novo. Como a interpretação das formas simbólicas é um processo ativo e mutante e oferece uma estrutura pessoal de apoio à mensagem, as maneiras de compreender os produtos da mídia são variáveis de acordo com os contextos culturais em que se inserem e de acordo com os indivíduos envolvidos.

0 trecho seguinte define melhor o que caracteriza a experiência hermenêutica da interpretação:

\footnotetext{
${ }^{5}$ Entende-se por produtos da mídia os programas de televisão, os livros, os jornais etc.

${ }^{6}$ Giovanni Sartori, mais à frente, vai tratar dessa questão dizendo que o processo cognitivo de ler um texto é diferente do de ver uma imagem.

${ }^{7} 0$ diálogo aqui sugerido não ocorre entre dois sujeitos distintos, e sim no processo cognitivo do intérprete.
} 
A principal tarefa do intérprete é descobrir a pergunta a que o texto vem dar resposta; compreender um texto écompreender a pergunta. Simultaneamente, um texto só se torna um objeto da interpretação se confrontar o intérprete com uma pergunta. Nesta lógica de pergunta e resposta, um texto acaba por ser um acontecimento ao ser atualizado na compreensão, que representa uma possibilidade histórica. Conseqüentemente, o horizonte do sentido é limitado e a abertura, tanto do texto como do intérprete, constitui um elemento estrutural na fusão dos horizontes. Nesta concepção dialógica, os conceitos usados pelo Outro, seja um texto, seja um tu, ganham nova força, por se inserirem na compreensão do intérprete. Ao entendermos a pergunta colocada pelo texto, fizemos já perguntas a nós próprios e, por conseguinte, abrimo-nos novas possibilidades de sentido (BLEICHER, 1992, p.161).

Também contribui para a estrutura que resvala a interpretação de informações mediadas, o contexto histórico em que o meio de comunicação está inserido. Nas sociedades modernas, ocorreu uma modificação cultural que é associada ao desenvolvimento tecnológico, mais especificamente à invenção da impressão e das mídias eletrônicas. Essas inovações proporcionaram um aumento da quantidade de informações disponíveis, pela facilidade com que se podia produzir e reproduzir as formas simbólicas. Além de revolucionarem a forma como os indivíduos lidavam com o tempo e com o espaço, alteraram as redes de comunicações preexistentes e, com isso, modificaram as relações de poder instituídas.

As novas redes de comunicação proporcionaram novas formas de relacionamentos sociais pela presença das novas tecnologias. A mudança foi tanto quantitativa, porque as novas formas de mediação baratearam e facilitaram a comunicação, quanto qualitativa ${ }^{8}$, porque a possibilidade de se alterar a relação entre tempo e espaço forçou a reorganização dos padrões de interação humana.

"0 desenvolvimento da mídia ajudou a criar um mundo em que os campos de interação podem se tornar globais em escala e em alcance e o passo da transformação social pode ser acelerado pela velocidade dos fluxos de informação" (THOMPSON, 2001, p.107). Ao levar as informações para indivíduos pertencentes a realidades culturais distintas, em locais remotos, a mídia está se envolvendo ativamente na construção das relações sociais, pois é capaz de modificar ou

\footnotetext{
${ }^{8}$ Queremos dizer que houve uma alteração na qualidade das relações humanas, o que não implica dizer que foi uma alteração para melhor.
} 
mesmo criar acontecimentos. Os indivíduos que estão distantes do local onde ocorreu um fato noticiado, por exemplo, travarão relações condizentes a ele que não aconteceriam se não tivessem tomado conhecimento. A expectativa por essas informações longínquas, que outrora não existiam, passou a fazer parte da cultura dos diversos grupos sociais. Cada grupo poderá estar distante de um acontecimento jornalístico, ao mesmo tempo em que poderá se sentir próximo, pois a mídia eletrônica proporciona essa sensação.

Os indivíduos envolvidos nos acontecimentos divulgados pela mídia farão parte do fato jornalístico que será transmitido para milhões de outros indivíduos, que farão suas próprias interpretações e terão entendimentos diferentes. Ao mesmo tempo, esses indivíduos que estão recebendo a informação poderão descobrir algo sobre o fato, mesmo que parcialmente, e isso altera e enriquece seus contextos sociais imediatos. Essa nova informação poderá ser adicionada à experiência do indivíduo e, a partir disso, poderá orientar suas ações.

Disso decorrem dois aspectos. Por um lado, a mídia eletrônica especialmente a televisão - tem o poder de selecionar e dar visibilidade a um acontecimento. Isso garantiu informação a um maior número de pessoas, de classes sociais não privilegiadas, que estariam excluídas em outras épocas. Devemos considerar esse fator como favorável à democracia, ou mesmo como uma possibilidade de lazer. Por outro lado, uma vez escolhido o fato mediado, a percepção sobre ele está prejudicada pela imposição do que Thompson chamou de "quase-interação mediada", que torna frágil a percepção sobre o fato noticiado. Nesse sentido, vale a pena conhecer os argumentos críticos de Giovanni Sartori sobre a videopolítica, em seu Homo videns.

\section{VIDEOPOLÍTICA}

A televisão, para Giovanni Sartori, empobrece o aparelho cognitivo do homem, transformando o Homo sapiens - produto da cultura escrita - em Homo videns - produto da imagem. Portanto, o ato de telever tem modificado a natureza do homem.

\footnotetext{
${ }_{9}^{9}$ Além da quase-interação mediada, que é aquela monológica proporcionada por um veículo de comunicação de mão única, como o rádio e a televisão, existe a interação mediada, que se faz com o auxílio de um meio de comunicação dialógico, como o telefone, e a interação face a face, que permite a comunicação no mesmo tempo e espaço, com uma multiplicidade de deixas simbólicas.
} 
A partir da vídeo-criança - aquela que está diante da televisão antes mesmo de aprender a ler e a escrever -, surge uma preocupação política baseada na primazia da imagem: prevalece o visível sobre o inteligível, que leva a ler sem compreender. Daí a justificativa da preocupação de Sartori com a videopolítica, isto é, do poder político da televisão.

$\mathrm{Na}$ televisão, o ver prevalece sobre o falar. A palavra torna-se coadjuvante da imagem. As coisas representadas em imagens ganham maior credibilidade que as coisas simplesmente faladas, de forma que hoje podemos dizer que "0 telespectador é mais um animal que vê do que um animal simbólico" (SARTORI, 2000, p.22).

0 saber do Homo sapiens se desenvolve na esfera de um mundus intelligibilis - de conceitos, de concepções mentais -, já que a própria linguagem é formada por palavras concretas, ou denotativas, e de palavras abstratas, de forma que a linguagem não está limitada ao mundus sensibilis, percebido pelos nossos sentidos. Assim, a televisão inverte o progredir do sensível para o inteligível e reverte-0, num regresso ao ver puro e simples. A televisão produz imagens e apaga os conceitos; mas, desta forma, atrofia a nossa capacidade de abstração e com ela toda a nossa capacidade de compreender (SARTORI, 2000, p.39).

Pela modificação da capacidade cognitiva humana, o vídeo passa a ser um instrumento potencial político. A televisão invade a vida dos homens recriando conceitos e agindo com informação em sua formação.

Na agenda política, a televisão também assume papel ativo, mais do que isso, modifica a forma do "ser político" e, conseqüentemente, a maneira como o político age. Em uma democracia, a relevância das opiniões faz com que a videopolítica ocupe papel central na dinâmica política. Os cidadãos podem formar sua opinião de acordo com o que vêem na tela, isso faz com que o político adapte sua imagem e suas ações ${ }^{10}$.

Assim, quanto mais a opinião pública passa a responder a fluxos de informação do poder político ou de instrumentos de informação de massas, mais a opinião do político está disposta a tornar-se "heterodirigida". Enquanto a opinião pública foi gerida pela imprensa escrita, houve um equilíbrio entre opinião autônoma e opinião heterônoma (heterodirigida). 0 desequilíbrio aparece com a televisão, na medida em que 0 ver suplanta o falar.

${ }^{10}$ A opinião pública pode exercer influência nos políticos não apenas no período das eleições, mas também durante os mandatos. 
Enquanto permanece a comunicação lingüística, os processos de formação de opinião não acontecem diretamente de cima para baixo; acontecem em 'cascata', ou melhor, como numa sucessão de cascatas interrompidas por bacias onde as opiniões se misturam. Além disso, à cascata juntam-se e contrapõem-se ebulições vindas de baixo, bem como resistências e viscosidades de várias naturezas (SARTORI, 2000, p.61).

Contudo, a força da imagem quebra esse sistema de equilíbrio. Com a televisão, a autoridade está na própria imagem, já que o olho acredita naquilo que vê. A imagem, portanto, surge como real, mas não significa, necessariamente, que o que se vê é verdadeiro. "É falso que a televisão se limita a refletir as mudanças em curso na sociedade e na sua cultura. Na verdade, a televisão reflete mudanças que em larga medida promove e inspira" (SARTORI, 2000, p.63).

No que se refere à informação de relevância pública, Sartori defende que a televisão informa pouco e mal. Para justificar, esclarece duas categorias importantes, usadas na classificação de notícias. Subinformação é a informação insuficiente que empobrece a notícia ou simplesmente não informa. Desinformação é a distorção da informação. São notícias falsas que enganam o receptor. A televisão, segundo o autor, é o instrumento de informação que menos informa, por conta do seu critério de seleção das notícias. As notícias são selecionadas de acordo com a facilidade de se obter uma imagem, de modo que a força da televisão de falar por imagens acaba sendo também o seu entrave.

Sartori acredita que o surgimento da videopolítica fez com que os partidos políticos estrategistas deixassem de ser indispensáveis. 0 voto no candidato e não no partido é cada vez mais freqüente. Os próprios políticos relacionam-se cada vez mais com acontecimentos midiáticos e cada vez menos com acontecimentos genuínos, ou seja, lidam com acontecimentos selecionados pela televisão, muitas vezes distorcidos e mal interpretados.

A palavra é menos aquecedora que a imagem, portanto, a cultura da imagem acaba com o delicado equilíbrio entre paixões e racionalidade. A racionalidade do Homo sapiens está a regredir. E a política emotiva, emocionada, aquecida pelo vídeo, levanta e atiça problemas sem fornecer qualquer idéia acerca da forma de os resolver. Acabando, assim, por agravá-los (SARTORI, 2000, p.106).

Partindo do princípio que o mundo por imagens, oferecido pelo videover desestimula a nossa capacidade de formular conceitos e compreender os problemas, é negativa a idéia de uma democracia direta ou um demos que se autogoverna. 
Para Sartori, o incentivo de uma maior participação política do cidadão é uma atitude irresponsável por conta do despreparo causado pela videopolítica. Um homem que perde a capacidade de abstração torna-se incapaz de raciocinar e reduz-se a um animal simbólico que não consegue sustentar, nem tampouco alimentar, o mundo construído pelo Homo sapiens. Um mundo construído por imagens pode ser desastroso para a formação de um animal racional. A televisão, portanto, ao enfraquecer a opinião pública ${ }^{11}$, pode inviabilizar a democracia e diminuir a capacidade do homem resolver concretamente seus problemas políticosociais.

\section{VISIBILIDADE}

A presença da televisão no cotidiano das pessoas alterou a abrangência da visibilidade. Isto porque um evento mediado pela televisão pode ser visível a milhões de pessoas, repetidas vezes, coisa que não ocorre a um evento testemunhado por meio de uma interação direta. Não é somente o número de pessoas a tomar conhecimento do mesmo fato que é ampliado, mas também a forma como esse fato é visto. 0 ângulo de visão proporcionado pela televisão é mais amplo. Um telespectador pode ver detalhes proporcionados pelo zoom da lente e pode ver o que não viu aquele que estava in loco com sua visão atrapalhada por um obstáculo.

Essa alteração de visibilidade representa também uma confusão do que é público e do que é privado. A presença da lente da televisão, como já observou Sartori, gerou alterações diretas no comportamento das pessoas - tanto governantes, quanto governados -, o que vamos examinar com maior cuidado também no pensamento de Thompson.

0 que é público está relacionado à idéia de visibilidade e o que é privado à idéia de invisibilidade. Podemos pensar as formas de governo segundo essa óptica. 0 modelo de democracia da Grécia antiga é um exemplo em que havia uma

\footnotetext{
${ }^{11}$ Esse ponto de vista pode ser reforçado pelo estudo desenvolvido por Fonseca (2005) a respeito da forma como a agenda ultraliberal foi consolidada no período de 1985 a 1992, quando a grande imprensa contribuiu incisivamente para a formação da opinião pública. Ainda que a discussão desse artigo esteja centrada nas mídias eletrônicas de massa, especialmente a televisão, a obra de Fonseca chama a atenção para aspectos ideológicos presentes em todos os meios de comunicação, além de nos permitir enunciar o debate a respeito do diálogo estabelecido entre mídia impressa e mídia eletrônica, no que diz respeito à pauta jornalística.
} 
visibilidade considerável na tomada de decisões. É possível imputar uma série de objeções ao modelo grego, como as restrições dos participantes da democracia e o tamanho das cidades-estado, que a tornava viável. No entanto, o que interessa é a idéia de um demos governando, que somente é possível por meio de uma transparência na tomada de decisões. 0 modelo dos estados monárquicos da Idade Média é o oposto. 0 absolutismo é caracterizado pela ausência total de visibilidade do governo, mas é caracterizado pela possibilidade de se governar muitos. 0 estado constitucional moderno é o meio-termo - busca governar muitos com o máximo de visibilidade. Ainda que a democracia grega não seja mais possível, a idéia de visibilidade está presente na democracia moderna, que voltaremos a analisar mais adiante.

A televisão é um dos elementos - talvez o principal - que altera a visibilidade de um governo. Ela funciona como um instrumento de controle oposto ao panopticon de Jeremy Benthan tratado por Michel Foucault. 0 modelo do panopticon descrito em Vigiar e Punir (2001) mostra como uma torre construída do centro de um presídio propicia que apenas um homem exerça a vigilância sobre muitos outros ao mesmo tempo. Nas sociedades hodiernas, esse modelo é empregado para formas de controle localizadas. Isso pode ser conferido pela presença de câmeras de segurança em algum estabelecimento público, por exemplo, em que é possível muitos indivíduos, ao se tornarem visíveis, serem vigiados por uma única pessoa. A televisão inverte o panopticon porque torna poucas pessoas visíveis a muitos. Com a presença da mídia, a visibilidade está em quem exerce o poder. A presença de uma imprensa vigilante se reflete nas ações do político. Isso pôde ser verificado com mais acuidade no Brasil depois do surgimento de algumas emissoras de televisão que instalaram câmeras que começaram a transmitir os trabalhos nos parlamentos. Com isso, os políticos passaram a cuidar mais de sua aparência e a freqüentarem mais as assembléias. Thompson (2001, p.127), nesse sentido, ilustra:

Aincapacidadedecontrolar ofenômeno davisibilidadeéumafontepermanente de problemas para os líderes políticos. Eles devem se policiar continuamente e empregar um alto grau de reflexibilidade para monitorar suas ações e expressões, pois um ato indiscreto ou uma observação inconseqüente podem, se forem gravadas e transmitidas a milhões de espectadores, ter desastrosas consequiências. 


\section{IMAGINÁRIo SOCIAL E TELEVISÃo}

Os imaginários sociais são pontos de referência dentro do vasto universo simbólico de qualquer coletividade e funcionam como matriz determinante de seus objetivos de ação e de sua identidade. Assim, o imaginário social é um elemento de poder e controle da vida em sociedade e é, por isso mesmo, um lugar de conflitos. Tornar esse mecanismo de controle e dominação suficientemente eficaz limita-se na proporção da difusão desse imaginário. Nesse sentido, os meios de comunicação oferecem a garantia de uma dominação simbólica que se iguala a qualquer outro meio de persuasão e repressão e excede a qualquer um deles em eficácia. "Os mass media fabricam e emitem, para além das informações centradas na atualidade, [...] os imaginários sociais: as representações globais da vida social, dos seus agentes, instâncias e autoridades [...]" (BACZKO apud LIMA, 1996, p. 242).

A linguagem, falada ou escrita, é uma criação social de significados pelo uso de símbolos e constitui-se em uma forma específica de uma consciência prática inseparável de qualquer atividade social material. A linguagem e a significação são indissolúveis do processo social, estando envolvidas na produção e na reprodução da realidade. Dessa forma, as representações que os media fazem, usando da linguagem e significação, passam a ser a própria realidade - são representações constituidoras da realidade e constituídas pela realidade.

A televisão ocupa, entre os media, lugar de destaque por sua audiência e credibilidade, especialmente nas sociedades ocidentais contemporâneas. A televisão tem sido responsável pela difusão do imaginário social construído em larga escala, mas sem descartar as demais mídias. Por sua abrangência, a televisão tem sido apontada como causa importante da reestruturação das relações entre os indivíduos e a cena política, alterando o papel que os partidos políticos tinham até o início do século XX, diluindo a identificação partidária de modo a substituir o partido político pelo político profissional ${ }^{12}$.

Pierre Bourdieu (1997), em seu livro Sobre a televisão, diz que o jornalismo, as pesquisas de audiência e a televisão são instrumentos de opressão que põe em

\footnotetext{
${ }^{12}$ Bernard Manin (1995) em As Metamorfoses do Governo Representativo fala que os meios de comunicação de massa assumiram o papel dos partidos políticos e do parlamento como fórum de debates. Os candidatos passaram a se comunicar diretamente com o povo, dispensando a mediação dos militantes partidários. Essa relação direta também ganhou novas características, como a valorização de particularidades do candidato e de questões que variam de eleição para eleição. Isso significou o declínio da política ideológica e da identidade partidária.
} 
risco a vida política e a democracia. A televisão, segundo ele, afasta o cidadão das informações que deveria receber para exercer seus direitos democráticos.

A solução para a catástrofe do jornalismo, apontada por Bourdieu, especialmente o jornalismo televisivo, estaria em uma nova forma de ver as imagens - uma forma sociológica em que haja o questionamento sobre o efeito do real, de modo a se poder usar a televisão como elemento de democratização de informações e não como um instrumento de opressão e violência simbólica ${ }^{13}$.

$\mathrm{Na}$ constituição da democracia, a pluralidade dos indivíduos com autonomia faz com que se busque uma constante unidade política a ser construída de baixo para cima, "através da obtenção hegemônica do consenso majoritário" (COUTINHO apud LIMA, 1996, p. 267). Com isso, fica evidente a importância dos media na constituição da democracia sendo um locus privilegiado de disputa de poder no mundo contemporâneo.

As questões que se levantam giram em torno da forma como esse poder dos media pode ser transferido para o conjunto da sociedade, para com isso justificar a prática democrática. A televisão surge como um contraponto pelo seu mecanismo de fruição, que parte de cima para baixo, por meio de uma indústria de massas, tornando a alienação propícia.

Com a mídia eletrônica, amplia-se o impacto receptivo na comunicação. Não apenas o aumento do espaço abrangido, mas o efeito no processo de cognição e o fascínio no imaginário do homem são elementos novos que a tecnologia trouxe para a midialogia. A televisão, mais especificamente, utiliza-se desse fascínio mítico que a tecnologia exerce sobre os homens e age mais sob a óptica da magia do que da informação. Essa prática, por sua vez, somente ocorre porque o homem - receptor - é dotado de imaginação, de ilusões, de incertezas.

A democracia é ameaçada não por conta de incapacidade racional do eleitor, mas por uma forma unilateral de se passar informação. "Cidadãos com pouca informação podem tomar decisões coerentes, mas apenas quando o debate público está aberto a uma pluralidade de interpretações sobre a realidade política" (PORT0, 1998, p.22). A quantidade de informações, portanto, não é o fator determinante, e sim a pluralidade de enquadramentos dos problemas que compõe o cenário de representação política. A construção da imagem do político, ou

\footnotetext{
${ }^{13}$ Sobre isso, Cf. Lima (1996) e Porto (1998), a respeito da importância da pluralidade de enquadramentos da notícia como solução para o "dilema democrático" gerado pela mídia de massas.
} 
mesmo do partido ou instituição, torna-se central na constituição e manutenção desse cenário ${ }^{14}$.

Grandepartedadisputapolítica, dabatalhaeleitoral aofuncionamentopolítico regular, da conquista da hegemonia por partidos ou outros agrupamentos de interesse à imposição das posições e pretensões na esfera pública deliberativa, tudo isso se resolve na forma de uma competição pela construção, controle e determinação da imagem de indivíduos, grupos e instituições participantes do jogo político (GOMES, 1999, p.1).

\section{Projeto Simbólico e Comunicação de Massas}

Existe hoje um problema a ser levado em conta que diz respeito ao deslocamento simbólico que os indivíduos enfrentam pela presença da mídia eletrônica. A causa está na mudança da relação tempo-espaço na vivência de experiências e aquisição de conhecimentos. Um indivíduo hoje tem a possibilidade de estar constantemente modificando seu léxico de experiências sem que para isso precise se deslocar. As informações chegam através de um aparelho, que exige o mínimo de esforço. 0 que antes só era conseguido por meio do encontro com outrem, hoje se consegue sozinho, com seu aparelho de televisão. A experiência que antes só acontecia mediante uma ação do indivíduo, hoje pode ser recebida digerida, da forma menos visceral possível. Esse processo constante de assimilação de conhecimentos e experiências já faz parte da rotina das pessoas e cada vez mais deixa de ser um problema para ser uma característica apriorística do processo de aquisição de conhecimentos. Ou seja, as pessoas cada vez menos conseguem viver sem a participação dos meios de comunicação eletrônicos na formação de seus valores.

Os indivíduos recebem um fluxo imenso de informações diariamente, mas o fazem de forma seletiva, dando maior atenção aos aspectos que mais thes interessam e descartando outros que não lhes despertam a curiosidade. Mas essa seleção também não é um processo simples, como se a subjetividade do receptor trabalhasse de forma semelhante a uma peneira. Ao receber uma informação, os indivíduos exercem um processo de decodificação que muitas vezes é um desafio cognitivo, pois é preciso relacionar algo que não é de seu domínio aos contextos de suas próprias vidas a fim de se obter algum sentido.

${ }^{14} 0$ conceito de CRP - Cenário de Representação Política - é originalmente citado por Venício Lima (1996). 
Thompson chama de self o projeto simbólico que o indivíduo está constantemente construindo. 0 termo emprestado da psicanálise traduz a idéia de uma somatória de materiais simbólicos que 0 indivíduo se apodera para construir sua própria identidade. Essa identidade vai se modificando conforme novas possibilidades simbólicas, novas expectativas e experiências são apresentadas ao indivíduo.

A fonte desses materiais simbólicos é variável. Pode não estar disponível a todos. Um indivíduo poderia construir seu projeto simbólico apenas por meio de experiências empíricas, o que refletiria uma particularidade muito grande, ou poderia buscar suas experiências e conhecimentos nos meios de comunicação. Nessas duas suposições, o resultado provavelmente seria opositivo. 0 que ocorre para a maior parte dos indivíduos, no entanto, é uma mescla dos dois casos. Dificilmente encontraremos alguém que viva em uma sociedade complexa que não tenha contato com a mídia. As fontes de informação podem ser um elemento de distinção entre os indivíduos. Isso é perfeitamente aceitável se pensarmos na exclusão digital, por exemplo. Nesse caso, a não-possibilidade de acesso de um indivíduo a determinada fonte de material simbólico, seja por um motivo técnico ou econômico, é um fator limitante, e ele possivelmente vai interpretar uma determinada informação de maneira diferente da de outro indivíduo que tenha acesso a ela. As condições materiais em que vivem os indivíduos também determinam o projeto de construçãa do self, pois a partir dessas condições criarão expectativas e valores que servirão de base para suas ações.

Conforme as experiências vão sendo cada vez mais mediadas pela presença das comunicações de massa, as relações de poder face a face vão perdendo sentido e vão sendo influenciadas por padrões estabelecidos pela mídia. Isso pode ser mais claramente entendido se pensarmos que o conhecimento implica em uma forma de poder (saber é poder) e que cada vez mais a mídia tem sido fonte de conhecimentos. Esse pensamento sugere que os indivíduos estão se modificando de maneira relativamente uniforme no que diz respeito aos padrões de aquisição de informação e isso concorda com a tese de Giovanni Sartori de que o aparato cognitivo humano está se modificando de acordo com a presença da mídia eletrônica.

Por outro lado, a presença da mídia eletrônica, ao fornecer novos tipos de material simbólico, fomentou a organização reflexiva do self. "Ela enriqueceu esta organização no sentido de que, quando os indivíduos têm acesso a formas mediadas 
de comunicação, eles se tornam capazes de usar um extenso leque de recursos simbólicos para construir o self" (THOMPSON, 2001, p.185). Esses materiais simbólicos são incorporados ao processo de formação do self e contribuem para sua organização.

O desenvolvimento da mídia eletrônica também possibilitou o aumento da capacidade de transmissão de mensagens ideológicas em contextos práticos da vida de uma população. Mas é necessário lembrar que o conteúdo dessas mensagens vai depender de como os indivíduos vão recebê-las, refletir e incorporá-las em seus projetos de formação do self e como vão usá-las na prática. De modo que o poderio ideológico de uma mensagem só pode ser quantificado de acordo com a forma como ela foi recebida.

Essas mensagens tendem a ser recebidas de maneira semelhante por indivíduos que estão sempre em contato com as mesmas fontes de materiais simbólicos. "Quanto mais o processo de formação do self se enriquece com as formas simbólicas mediadas, mais o indivíduo se torna dependente dos sistemas da mídia que ficam além do seu controle" (THOMPSON, 2001, p.187). A vida imaginativa, por sua vez, passa por uma atrofia condizente à constância das formas simbólicas dadas de maneira inflacionada. 0 indivíduo, ao receber expectativas e conhecimentos de forma mediada, acomoda-se.

\section{Cultura de Massas}

Passaremos agora a refletir os argumentos que tratam a cultura de massas e a influência dos media sobre ela. A relevância de se pensar sobre a cultura de massas está na crença de que ela nada mais é que um "self coletivo". Um conjunto de materiais simbólicos que propicie uma maior conscientização política, por meio de uma influência direta nessa cultura, pode vir a representar uma maior participação da população na democracia.

Segundo Hans Enzensberger (1978), a mídia eletrônica proporcionou um aumento de influência na "consciência" da sociedade. Para tratar essa idéia, usa 0 termo "indústria da consciência". Enzensberger, a partir da diferenciação técnica existente entre 0 emissor da informação e o receptor, faz uma analogia com a divisão social do trabalho. A distinção entre produtores e consumidores ganha um sentido especial na indústria da consciência: "em última análise, ela está baseada na contradição essencial entre as classes dominantes e as dominadas (isto é, entre o capital e a burocracia monopolista de um lado, e as massas dependentes do 
outro)" (ENZENSBERGER, 1978, p.45), o que implica reconhecer que o poder dos detentores dos meios de produção midiáticos é particularmente importante por agir na consciência das pessoas. 0 argumento é interessante por identificar, no poderio econômico, uma segunda possibilidade de poder, o simbólico. Pela lógica proposta pelo autor, a classe dominante não só detém os meios de produção que lhes garante poderio econômico, como detém os meios de produção de consciência, que lhes assegura esse poder.

A participação das massas - nessa lógica - reduz-se a escolher uma programação estabelecida pelos emissores e a recusar a recepção, desligando seus aparelhos. Isso já é um ponto a se considerar. É o indivíduo que detém o poder de ligar ou não o seu aparelho receptor - ação redentora. No entanto, indivíduos que são capazes de desligar sua televisão porque se percebem manipulados, são indivíduos críticos que, em princípio, não nos preocupam. Resta saber o que ocorre aos demais, os que recebem a informação proposta por essa classe dominante.

0 cerne do problema encontrado na qualidade de uma informação mediada está, talvez, na impossibilidade de um feedback que um meio eletrônico como a televisão e o rádio não proporcionam. Segundo Enzensberger, "na sua forma atual, técnicas como a televisão e o cinema não estão a serviço da comunicação, mas até lhe são obstáculo" (ENZENSBERGER, 1978, p.49). Isso porque a comunicação não é recíproca. Se os aparelhos fossem ao mesmo tempo receptores e emissores e as massas tivessem a oportunidade de responder às mensagens com anseios, sugestões e questionamentos, as mídias eletrônicas seriam excelentes e autênticos meios de comunicaçãa ${ }^{15}$. É bem verdade que em uma interação face a face também existe a possibilidade de dominação, mas essa dominação tem de ultrapassar obstáculos existentes em uma relação de co-presença, como o questionamento de idéias. Uma vez reconhecida a natureza monológica ${ }^{16}$ dos meios de comunicação de massa, a forma como as mensagens são vinculadas requer atenção.

\footnotetext{
${ }^{15}$ Vale lembrar que a Internet, por meio do recente fenômeno dos blogs, traz a possibilidade de uma comunicação mais substantiva que outros meios de comunicação de massa. De acordo com pesquisas recentes sobre blogs de política, no entanto, não se verifica um bom aproveitamento do potencial de participação trazido por essa Nova Tecnologia de Comunicação e Informação. De forma geral, os blogs que tratam de assuntos políticos reproduzem o formato jornalístico, e seus leitores exercem muito pouca influência sobre a pauta, limitando-se a tecer comentários superficiais que, muitas vezes, fogem do tema discutido. Sobre esse tema, cf. Araújo; Burgos e Penteado (2007).
}

${ }^{16}$ Aqui referimo-nos ao termo stricto sensu. 
Giovanni Sartori, Pierre Bourdieu e Enzensberger não hesitam em dizer que a televisão manipula a informação. É importante definir o objeto, pois isso tem sido alvo de polêmica entre os estudiosos da mídia. Manipular a informação é diferente de manipular o receptor. A hipótese da hermenêutica a que Thompson se apega não elimina a idéia de manipulação da informação, apenas atribui ao processo de recepção uma roupagem dinâmica que tira a idéia de que 0 receptor é um títere. Os argumentos dos três autores acima são relevantes porque permitem verificar que uma mensagem mediada pode sofrer transformações em escalas variáveis, representadas por acréscimo ou omissão de informação, ou mesmo um incremento narrativo que pode vir a causar significados novos e intencionados.

Mauro Porto, ao trabalhar o conceito de enquadramento (framing), observa algumas práticas específicas - seleção, ênfase, exclusão - dos mídia, que organizam o discurso e constroem determinada interpretação de um fato noticiado. A definição que apresenta sobre o conceito é esclarecedora:

Os enquadramentos da mídia [...] organizam o mundo tanto para os jornalistas que escrevem relatos sobre ele, como também, em grau importante, para nós que recorremos às suas notícias. Enquadramentos da mídia são padrões persistentes de cognição, interpretação e apresentação, de seleção, ênfase e exclusão, através dos quais os manipuladores de símbolos organizam o discurso, seja verbal ou visual, de forma rotineira (GITLIN apud PORTO, 2002, p.4).

Enzensberger (1978, p.67) busca a origem da palavra manipulação para mostrar que o termo significa uma "consciente intervenção técnica em um material dado". Uma vez que essa intervenção ocorre em um material simbólico veiculado pela televisão, adquire uma importância social imediata e constitui um ato político.

Assim, pois, toda utilização dos meios pressupõe uma manipulação. 0s mais elementares processos de produção, desde a escolha do próprio meio, passando pela gravação, o corte, a sincronização e a mixagem, até chegar à distribuição, constituem intervenções no material existente. Portanto, escrever, filmar ou emitir sem manipulação não existe (ENZENSBERGER, 1978, p.67).

A questão, portanto, não é se a televisão manipula ou não, e sim, quem manipula os produtos da mídia. Essa idéia nos faz voltar toda a atenção para a perspectiva de que os donos dos meios de produção possuem objetivos implícitos 
no controle da comunicação de massa e esses objetivos - políticos e econômicos - devem residir como pano de fundo de nossa análise ${ }^{17}$.

Vejamos agora os argumentos de Umberto Eco sobre a cultura de massas e a influência dos media sobre ela. 0 tipo de mensagem veiculada pela televisão segue uma homogeneidade para atingir o maior número de pessoas. Ao difundir uma cultura de tipo homogênea, os mass media alteram as características culturais próprias de cada grupo social. Esse espectador atingido pela mensagem televisionada não está consciente de que forma um grupo social caracterizado e "portanto não pode manifestar exigências nos confrontos com a cultura de massa, mas tem que sofrer-lhe as propostas, sem saber que as sofre" (ECO, 1970, p.40). Isso implica dizer que o indivíduo pertencente a um grupo social justifica sua condição por meio de características que não são necessariamente de seu conhecimento. Essa visão contribui para pensarmos na idéia de massa e também na idéia de uma cultura coletiva que serve de estrutura para o que Thompson chamou de self.

Os detentores dos meios de produção da informação estão inseridos em uma realidade mercadológica e, com objetivos econômicos, ofertam ao seu público somente o que ele quer, ou então, por meio da persuasão da publicidade, sugerem ao público o que ele deve desejar. No mais, a forma como faz isso segue o caminho mais fácil e seguro para o cumprimento de objetivos mercadológicos. "Ao invés de simbolizarem uma emoção, de representá-la, provocam-na; ao invés de a sugerirem, entregam-na já confeccionada. Típico, nesse sentido, é o papel da imaginação em relação ao conceito; ou então da música, como estímulo de sensações mais do que como forma contemplável" (EC0, 1970, p.40). Essa maneira de informar estimula a preguiça do receptor em buscar novas experiências e de criar uma consciência histórica, pois os fatos são encarados de uma perspectiva imediata que ignora a relação de causa e efeito entre presente, passado e futuro.

A homogeneização das mensagens da mídia é caracterizada pela presença de símbolos e mitos de fácil universalidade, que criam "tipos prontamente reconhecíveis e reduzem, por isso, ao mínimo, a individualidade e o caráter concreto não só de nossas experiências como de nossas imagens, por meio das quais devemos realizar experiências" (EC0, 1970, p.41). Isso contribui para uma

\footnotetext{
${ }^{17}$ Essa questão ganha especial relevância quando se trata de acompanhar os meios de comunicação durante períodos eleitorais. Diferentes pesquisadores têm produzido estudos relevantes nesse sentido. Como exemplo, podemos citar o projeto coordenado por Chaia (2002), que envolveu esforços de diversos pesquisadores de diferentes universidades.
} 
ação conservadora e estagnada, pois os receptores, ao se identificarem com esses símbolos universais, têm a sensação de estarem continuamente confirmando seus pensamentos. Essa presença contínua de elementos familiares estimula um conformismo nos valores e costumes e a postura da mídia tende a ser tomada por uma postura inquestionável. Os mass media, portanto, parecem formar uma típica superestrutura capitalista voltada para a manutenção do regime e para a alienação. A idéia otimista de que a mídia incrementa as experiências dos indivíduos, como levantou Thompson, para Humberto Eco, portanto, não passa de um "mascaramento ideológico de uma estrutura econômica precisa, fundada sobre o consumo, para o consumo" (p.43).

Alguns pontos podem ser ditos em favor da cultura de massa, como o fato de não ser típica do regime capitalista e sim de uma sociedade de tipo industrial, do contrário não haveria cultura de massas em regimes socialistas.

Toda a cultura artística da (antiga) União Soviética é uma típica cultura de massa, com todos os defeitos de uma cultura de massa, entre os quais o conservadorismo estético, o nivelamento do gosto pela média, a recusa das propostas estilísticas que não correspondem ao que o público já espera, a estrutura paternalista da comunicação dos valores (EC0, 1970, p.44).

A cultura de massa, na verdade, não veio substituir uma outra cultura superior. Ela simplesmente se difundiu a partir dos meios de comunicação em populações que antes não tinham acesso a bens de cultura. Isso é entendido quando pensamos em uma época em que poucos sabiam ler e escrever e a cópia de livros era feita manualmente. A cultura da população era limitada a costumes passados oralmente e ficavam restritos espacialmente pela dificuldade de mobilidade. Os meios de comunicação de massa puderam difundir para um número imenso de pessoas, situadas em locais distantes, um conhecimento comum. A qualidade desse conhecimento é questionada por primar por uma simplificação, mas Umberto Eco (1970, p. 45) apresenta um argumento interessante:

0 homem que assobia Beethoven porque o ouviu pelo rádio já é um homem que, embora no simples nível da melodia, se aproximou de Beethoven (nem se pode negar que, já nesse nível, se manifesta, em medida simplificada, a legalidade formal que rege nos outros níveis, harmônico, contrapontístico etc., a obra inteira do musicista), ao passo que uma experiência do gênero era, outrora, privativa das classes abastadas, entre cujos representantes, muitíssimos, provavelmente, embora submetendo-se ao ritual do concerto, fruíam a música sinfônica no mesmo nível de superficialidade. 
Ocorre que, na comunicação de massas, muitos elementos de informação verídicos estão misturados a curiosidades e entretenimentos, mas negar que esse acúmulo de informações quantitativas não possa resultar em estímulos qualitativos para algumas pessoas, é uma posição pessimista demais sobre a condição humana.

0 principal problema da cultura de massa, para Umberto Eco, é ela ser controlada por grupos econômicos que obedecem às leis de mercado para obter o lucro, sem que tenham que passar pelo crivo de uma discussão ampla sobre sua qualidade. Ao mesmo tempo, enganam-se os que acreditam ser possível uma cultura de massa subtraída ao condicionamento industrial. Uma vez que a mesma é um produto industrial, a única coisa a ser feita é buscar formas para que os meios de comunicação possam veicular valores culturais enriquecedores.

\section{Comunicação de Massa e Democracia}

0 modelo de democracia tal qual se viu na Grécia antiga, como já vimos, não é possível nas sociedades atuais. 0 modelo democrático constitucional busca conciliar a representatividade e a participação dos cidadãos com os problemas apresentados por um mundo globalizado e complexo, mas não sem apresentar alguns problemas. A instituição do novo modelo representativo gerou um desencantamento dos indivíduos em relação às instituições políticas, pois as decisões ficaram restritas a políticos profissionais e a participação dos demais cidadãos passou a ser restrita a um diminuto período eleitoral. Além disso, o modelo deve subsistir a uma realidade de distinção de classes imposta pela lógica do capital, o que gera diferenças na participação política dos cidadãos. 0 modelo também fornece uma série de regras que limitam as ações dos partidos políticos que, ao se adaptarem a essas regras, podem deixar de lado as demandas sociais.

Luiz Felipe Miguel (2003) apresenta a questão a partir da existência de uma crise da representação política assentada por três indícios: o declínio da participação eleitoral, o aumento da desconfiança das instituições políticas e a crise dos partidos, que teriam deixado de representar os interesses da população. A representação política, segundo Miguel, vai além da escolha dos representantes políticos pelo processo eleitoral e possui outras duas dimensões: a participação na definição da agenda política e a existência de esferas públicas concorrentes, a partir das quais os diferentes grupos que formam a sociedade podem expressar seus 
próprios interesses. Assim, os meios de comunicação de massa se configuram como uma das esferas da representação política, além de contribuírem para o significativo processo de mudança nas três dimensões da referida crise de representação.

Esses problemas poderiam ser minimizados, segundo Thompson, por meio da idéia de democracia deliberativa, já que a participativa direta é inviável pela ausência de conjunturas necessárias para a sua implantação em uma sociedade complexa. Ademocracia deliberativa buscaria diminuir a distância entre os eleitores e seus representantes tratando "todos os indivíduos como agentes autônomos, capazes de formar juízos razoáveis através da assimilação de informações e diferentes pontos de vista", institucionalizando "uma variedade de mecanismos para incorporar os juízos individuais num processo coletivo de tomada de decisão" (THOMPSON, 2001, p.220). Mais do que pensar em uma proposta - talvez inexeqüível num mundo de desigualdades -, a idéia de democracia deliberativa traz um elemento importante para se pensar o papel da mídia, pois esse modelo "focaliza a atenção nos processos pelos quais os juízos são formados e as decisões são tomadas" (THOMPSON, 2001, p.220).

A presença dos meios de comunicação de massa exerce influência direta na formação desse juízo. Mesmo não existindo praticamente mecanismos que fazem valer a opinião dos eleitores numa discussão política, e ela aconteça apenas entre os representantes eleitos, a formação desse juízo é determinante para a eleição desses representantes. A arena deliberativa poderia ocorrer, por exemplo, em associações de bairro e em partidos políticos, o que já seria um salto qualitativo para a conscientização política da população. Essa participação exige o mesmo nível de encantamento pela política que uma assembléia deliberativa exigiria, e a mídia é o elemento que pode despertar esse interesse, pelo seu poder de visibilidade. As instituições da mídia, portanto, deveriam ser responsáveis por uma politização que somente pode ser realizada mediante uma exposição variada de pontos de vista sobre um mesmo fato (PORT0, 1998). Com isso, os indivíduos poderiam formar juízos de valor sobre assuntos de seus interesses.

\section{REFERÊNCIAS}

ARAÚJ0, Rafael; BURGOS, Marcelo; PENTEADO, Cláudio. Internet e Política: os blogs nas eleições presidenciais 2006. In: ENCONTRO ANUAL DA ANPOCS, 31, Caxambu, 2007. 
BLEICHER, Joseph. Hermenêutica Contemporânea. Lisboa: Edições 70, 1992. BOURDIEU, Pierre. Sobre a Televisão. Rio de Janeiro: Jorge Zahar, 1997.

CHAIA, Vera. (Coord.) Projeto Temático FAPESP: Mídia, Campanha Eleitoral e Comportamento Político em São Paulo nas eleições de 2000 e 2002. Disponível em http://www.pucsp.br/neamp> Acesso em: out. 2002.

ECO, Umberto. Apocalipticos e Integrados. São Paulo: Perspectiva, 1970.

ENZENSBERGER, Hans-Magnus. Elementos para uma teoria dos meios de comunicação. Rio de Janeiro: Tempo Brasileiro, 1978.

FONSECA, Francisco. O Consenso Forjado: a grande imprensa e a formação da Agenda Ultraliberal no Brasil. São Paulo: Hucitec, 2005.

FOUCAULT, Michel. Vigiar e Punir. Petrópolis: Vozes, 2001.

FREITAG, Bárbara; ROUANET, Sérgio Paulo. (Org.). Habermas. São Paulo: Ática, 1993.

FREUND, Julien. Sociologia de Max Weber. Rio de Janeiro: Forense Universitária, 2000.

GOMES, Wilson. A Política de imagem. Belo Horizonte: COMPÓS, 1999.

LIMA, Venício. Os Midia e o Cenário de Representação da Política. Lua Nova. Revista de Cultura Política. Cedec, n. 38, São Paulo, 1996, p.239-271.

MANIN, Bernard. As Metamorfoses do Governo Representativo. Revista Brasileira de Ciências Sociais, n. 29, São Paulo, out. 1995, p. 5-34.

MIGUEL, Luis Felipe. Representação política em 3-D: elementos para uma teoria ampliada da representação política. Revista Brasileira de Ciências Sociais, v.18, n.51, São Paulo, fev. 2003.

PORTO, Mauro. Muito além da informação: mídia, cidadania e o dilema democrático. São Paulo em Perspectiva, v.12, n.4, São Paulo, out./dez., 1998, p. $17-25$.

Enquadramentos da Mídia e Política. In: ENCONTRO ANUAL DA ASSOCIAÇÃO NACIONAL DE PÓS-GRADUAÇÃO E PESQUISA EM CIÊNCIAS SOCIAIS. ANPOCS, 26, Caxambu, 2002.

SARTORI, Giovanni. Homo Videns: televisão e pós-pensamento. Tradução de Simonetta Neto. Lisboa: Terramar, 2000.

THOMPSON, John B. A Mídia e a modernidade: uma teoria social da mídia. Petrópolis: Vozes, 2001. 